\title{
Wampirologia albo - jak się staje, czym się jest
}

Andrzej Skrendo

TEKSTY DRUGIE 2016, NR 2, S. 431-440

DOI: $10.18318 /$ td.2016.2.24

W

książce Lehren der Kontingenz [Nauka przygodności'] Siegfried J. Schmidt wśród wielu anegdot i wspomnień zamieszcza i tę: o tym, jak pod koniec lat 60 . wraz z kolegami z Karlsruhe wystawił sztukę satyryczną Vampirologie [Wampirologia]. Tematem przedstawienia było m.in. wykorzystanie wampirów jako sierżantów w Bundeswehrze oraz użycie małych wampirów indonezyjskich do roli opiekunek dla dzieci i pomocy domowych. Co ważne, Schmidt nie grał wampira, lecz szefa Centrum Badań nad Estetyką Wampiryczną w Todtnaubergu. Sztuka odniosła nadspodziewany sukces i została powtórzona w miejscowej rozgłośni radiowej.

Dlaczego opowiadam o tym epizodzie (i czy aby na pewno jest to epizod)? Z wielu powodów. Najpierw po to, aby dać pojęcie o wyjątkowej pozycji książki Nauka przygodności w przepastnym dorobku Schmidta. Jak głosi jej podtytuł, są to wspomnienia z 40 lat „życia podwójnego" (Erinnerung an 40 Jahre Doppelleben), czyli zapis

1 Lehren der Kontingenz. Erinnerung an 40 Jahre Doppelleben, Lit Verlag, Berlin 2012.
Andrzej Skrendo profesor Uniwersytetu Szczecińskiego, teoretyk i historyk literatury, krytyk literacki. 
pożegnalnych wykładów wygłoszonych na Uniwersytecie w Münster w latach 2005-2006, w których miesza się egzystencja z teorią. I stąd anegdoty. Ale sensów owej podwójności jest wiele. Ten bezpośrednio przez Schmidta wskazany, choć bynajmniej - moim zdaniem - nie najważniejszy, to podwójność jego biografii twórczej, fakt, że uprawiał on jednocześnie naukę i sztukę (poezję konkretną). Inny sens, również wyjawiony przez samego Schmidta, polega na tym, że tworzy on własną opowieść biograficzną, będąc jednocześnie teoretykiem auto- i biografizmu (Lehren der Kontingenz to pierwszy tom serii oficyny LIT Wissenschaft biografisch [Nauka biograficznie]). Mamy tu do czynienia z podwójnością z tego powodu, że dwa wymienione nastawienia sam Schmidt zwykle mocno przeciwstawiał zgodnie z odróżnieniem udział w badaniu systemu literatury/badanie systemu literatury ${ }^{2}$. Tymczasem w Nauce przygodności próbuje umieścić swoją opowieść na pograniczu tych sposobów działania, odróżniając naukę od rozrywki (Unterhaltung) i zadając symptomatyczne pytanie: „Ale kto boi się rozrywki?”. Wspomniane odróżnienie, co wielce znaczące, nazywa „typowo niemieckim tematem” (s.10), w sensie: przesądem. Tym samym dowartościowuje to, co dotąd cenił zdecydowanie mniej. Czy jednak, mimo całej ironii, udało mu się nie ulec przesądowi? Wolno w to wątpić. Jak się zdaje, w sporej mierze nadal pozostaje jego niewolnikiem - z tego powodu, że żywioł biograficzny jest w jego książce mocno ograniczony, podporządkowany narracji naukowej i obecny tylko na tyle, na ile pozwalają na to silne założenia teoretyczne (czytamy w otwierającej tom krótkiej nocie Wyznania win: „A teraz proszę o uwagę dla konstrukcji pamięci, zwanej moim życiem", s. -i- ). Owe założenia polegają m.in. na tym, że należy wyzbyć się nadziei na obiektywne przedstawienie przeszłości, bo to niemożliwe, a w zamian jasno i otwarcie wysłowić własną sytuację - punkt obserwacji, w którym się znajdujemy ${ }^{3}$. Nie jest to przyzwolenie na dowolność, w żadnym razie!, lecz przeciwnie: zobowiązanie do podjęcia trudu racjonalizacji własnych wyborów z przeszłości. Tak czy inaczej, to, co można by nazwać prywatnością czy intymnością, w Schmidtowskim projekcie w zasadzie nie pojawia się i pojawić się nie może.

2 Przede wszystkim w książce Grundriss de Empirischen Literaturwissenschaft. Mit einem Nachwort zur Taschenbuchausgabe, Suhrkamp, Frankfurt am Main 1991. Szerzej o dorobku Schmidta patrz: B. Balicki Empiryczna Nauka o Literaturze, "Teksty Drugie” $2010 \mathrm{nr}$ 4. Zob. też niezwykle pożyteczny tom Radykalny konstruktywizm. Antologia, red. B. Balicki, D. Lewiński, B. Ryż, E. Szczerbuk, Centrum im Willy'ego Brandta, Wrocław 2010.

3 Schmidt powołuje się tu na tom: H. von Foerster, E. von Glasersfeld Wie wir uns erfinden Eine Autobiographie des radikalen Konstruktivismus, Carl-Auer, Heidelberg 1999. 
Warto do razu zaznaczyć, że przedstawione założenia to tylko pozorne wyjście ze starego problemu autobiografizmu zwanego zwykle (myląco) szczerością. Żeby to sobie uświadomić, warto wrócić do słowa „lęk”. Schmidt sporo mówi o swoim naznaczonym lękiem i biedą dzieciństwie (nazywa siebie mianem „bewegte Kind” i, podążając za tym określeniem, należałoby powiedzieć, że miał on „burzliwe dzieciństwo w niespokojnych czasach”). Podkreśla, że najważniejsze doświadczenia, które potem na zawsze określają nasze wybory, przeżywa się do szóstego roku życia. W jego wypadku - Schmidt to rocznik 1940 - były to czas wojny i pierwszy rok po jej zakończeniu. Po latach Schmidt myśli bardzo surowo o tym, co nazywa się niekiedy niemiecką winą. Pozostaje niezwykle krytyczny wobec myślenia czy raczej niemyślenia Niemców o nazizmie w erze Adenauera (do roku 1963, w istocie: 1968). Podkreśla, że wzięto wówczas „urlop od historii” oraz wybrano dobrobyt zamiast prawdy („Wohlstand statt Wahrheit”; użycie tych znanych formuł jest swego rodzaju sygnałem orientacyjnym). Przy tym wydaje się rzeczą osobliwą, że zastanawiając się nad znaczeniem wczesnego dzieciństwa w swym dalszym życiu, Schmidt nie powołuje się na autorytet psychoanalizy, jak można by się spodziewać, ale na... Rogera Watersa z zespołu Pink Floyd. To on, jak wynika z wywodu Schmidta, wypowiedział tę brzemienną w znaczenia myśl, że „Do 6 roku życia zostają wyuczone wszystkie ważne schematy działania i odczuwania, potem nie wydarza się już wiele ważnego" (s. 7). Ta podmiana Freuda przez Watersa może trochę zaskakiwać i każe sformułować uwagę nieco sceptyczną: Schmidt, w rzeczy samej, ujawnia miejsce, z którego mówi (niekiedy w osobliwy sposób), co jednakowoż nie usuwa niejasności związanych z owym usytuowaniem czy może raczej nie czyni go mniej problematycznym albo mniej zagadkowym.

Wracając jeszcze do kwestii wampiryzmu i podwójności: zwróćmy uwagę, że bycie wampirem to rodzaj życia podwójnego (czy podwojonego). Dysponowanie niezwykłymi siłami. Czerpanie życiodajnych mocy z wielu źródeł, chciałoby się powiedzieć: permanentna praca w ludzkiej grupie. Sposobność do nieustannego przemyśliwania relacji między tym, co ludzkie, a tym, co nie ludzkie. Wielce osobliwy, zaniedbywany przez naukę, ale jakże doceniany przez sztukę, zwłaszcza niemiecką, tak silnie eksponującą postać Doppelgängera - sposób doświadczania przygodności. Może właśnie dlatego sama nauka, jak nieustannie przekonuje Schmidt, nie może nam wystarczyć, bo niewiele ma do powiedzenia o różnych, chwalebnych, formach podwójności? A teraz: czyż czytelnik Schmidta, porażony wielkością jego dorobku (autorskiego, współautorskiego i redaktorskiego: idzie w setki), jest w stanie oprzeć 
się podejrzeniu, że Schmidtów jest (co najmniej) dwóch? Że jego siły pisarskie i dynamika myśli przekraczają ludzkie miary, a źródło owej mocy wraz z narastaniem dorobku tajemniczeje coraz bardziej? Że nie bez (wampirycznego) powodu tak chwali on to, co nazywa Teamarbeit? A czyż sekret jego pisarstwa nie polega na tym, że wysysa on krew z coraz to nowych obiektów pojawiających się na horyzoncie badawczym (mód, prądów, teorii), przyswajając to, czego potrzebuje do własnego wzrostu, a swe ofiary pozbawiając siły i atrakcyjności? Czy to przypadek, że dwa razy (!) w swej opowieści wspomina o tym, iż oskarżano go, jako poetę konkretnego - czyli tego, który nie opowiada - o bycie nieludzkim („inhuman”, s. 20; „unmenschlich”, s. 82). A czyż figura wampira nie wydaje się szczególnie wdzięcznym tematem dla poety konkretnego, który - jak tłumaczy Schmidt - zajęty jest głównie rozpatrywaniem relacji między słowem i pojęciem (zob. s. 20)? Może właśnie z tych powodów Schmidt podjął swe przedsięwzięcie biograficzne i dlatego próbuje pogodzić się z żywiołami rozrywki, gadania, rozmowy - żeby zaprzeczyć podejrzeniu, że owa sztuka o wampirach nie była tylko epizodem, lecz czymś dużo ważniejszym, mianowicie jednym z tych nielicznych zdarzeń, które - choć przyszły po skończeniu szóstego roku życia - mają w jego życiu rozstrzygające znaczenie?

Ale odwróćmy to rozumowanie - i bądźmy poważniejsi! Przecież Schmidt nie grał wampira, ale badacza wampirów... Dodatkowo z miejscowości, której nazwa nie jest nieznana... Otóż powiedzielibyśmy tak (a jest to teza śmiertelnie poważna): praca naukowa Schmidta była częściowo badaniem, a przede wszystkim szukaniem alternatywy dla tradycji niemieckiej germanistyki (czy szerzej i po prostu - Geisteswissenschaften), która dla Schmidta jawiła się jako tradycja wampiryczna. A to znaczy: hermeneutyczna, romantyczna, nacjonalistyczna; tradycja niejako pasożytująca na żywym organizmie niemieckiej kultury i wysysająca z niej siły, a przez to uniemożliwiająca pożądaną zmianę. Najpoważniejszą figurą tej tradycji staje się Martin Heidegger, dla którego Schmidt nie potrafi znaleźć dobrego słowa (i którego wykładu słuchał w latach swej młodości). Heidegger, którego nie tyle nawet krytykuje, ile potępia. Owa niechęć to jeden z powodów, dla których Schmidt odrzuca też wszystko to, co uznaje za postmodernizm i dekonstrukcję - choć czasem, ale tylko, jak sądzę, z powodów taktycznych, szuka wspólnoty własnych dążeń z owymi dwoma prądami. Jest to kwestia niezwykle istotna dla losów Schmidtowskiego konstruktywizmu poza Niemcami: owa silna opozycja wobec dominacji hermeneutyki, ale nie tyle hermeneutyki jako takiej, ile tej będącej częścią 
szerokiego kontekstu kulturowego występującego w powojennych Niemczech. Oto zatem kolejna ważna podwójność: filozofia Schmidta musi być rozpatrywana jako próba stworzenia przeciwwagi dla czegoś, co nie do końca żartobliwie należałoby nazwać niemiecką tradycją wampiryczną. Próba rozumienia Schmidta poza tym kontekstem z definicji będzie skazana na połowiczność. Wydaje mi się, że Nauka przygodności w mocnym sensie mówi o tym związaniu z tradycją kultury i polityki Niemiec - wprost i nie wprost. Związaniu właśnie - podkreślmy - a nie po prostu i jedynie szukaniu alternatywy.

Schmidt, gdy przedstawia sens swego przedsięwzięcia, powiada (za Johnem Kotrem), że kiedy nadaje się formę własnym wspomnieniom, nadaje się też formę samemu sobie - a trzeba być spójnym („Man macht sich kohärent”, s. 11)! Jeśli by tak pomyśleć, nauka przygodności, którą przedstawia Schmidt, byłaby raczej nauką ucieczki od przygodności niż jej doświadczaniem lub afirmacją. W ujęciu teoretycznym, które odgrywa ważną rolę, przygodność zostaje „wyjaśniona” (i okiełznana) w taki oto sposób: „Kierunek rozwoju ogólnie może zostać określony jako przyrost kompleksowości, który idzie w parze z przyrostem przygodności i rozproszenia" (s. 59). Ujęciu temu w jakiś nieprzyjemny sposób - ale ta nieprzyjemność jest czymś cennym! - towarzyszy, by tak rzec, wiele innych przygodności, które z powodu swego trywialnego charakteru nie dają się bezkonfliktowo podciągnąć pod teoretyczną regułę. Na przykład zachwyt nad jazzem w powojennych Niemczech okazuje się, według Schmidta, przejawem przygodności, gdyż kultura towarzysząca tej muzyce była pozbawiona korzeni - zupełnie inaczej niż w USA (s. 18). Inny przykład to pytanie, na ile przygodny jest przypadek, który sprawia, że ktoś podejmujący studia napotyka lub decyduje się na takie a nie inne metody, tematy, dziedziny, cele i - last but not least - tych, a nie innych nauczycieli? (s. 26). Zatrzymajmy się tu: „Na ile przygodny jest przypadek?” (Wie kontingent ist aber dann der Zufall?) to istotnie ciekawe pytanie. W rozbudowanej wersji brzmiałoby ono tak: czy przygodność, o ile staje się częścią szerszej struktury teoretycznej, o ile zostaje wpisana w jakąś całość, przygodność tracąca swój agresywny i, by tak się wyrazić, nomadyczny charakter (tak jak nomadyczne było naznaczone ciągłym przenosinami dzieciństwo Schmidta) - czy taka przygodność jest jeszcze przygodnością? Czy nie staje się czymś innym, powiedzmy - korelatem czy może nawet hipostazą struktury teoretycznej? A nawet - jeśli wolno tak zapytać (pewnie nie wolno): czy jest ona narzędziem opisu, czy jakością samego doświadczenia? Schmidt nie daje w tej sprawie jasnych odpowiedzi. 
Jak łatwo zauważyć, moja lektura niejako wygrywa jedną stronę narracji Schmidta przeciw drugiej (znów ta podwójność!): tę szczęśliwie (sic!) naznaczoną pesymizmem i zwątpieniem przeciw tej niefortunnie optymistycznej i konstruktywnej. Lektura ta opiera się na sugestii silnie, ale z ukrycia przebijającej się w Nauce przygodności, że - niech mi będzie wolno raz jeszcze odwołać się do wcześniej używanych metafor - „nieludzki”, scjentystyczny, twardy, niekiedy wręcz bezduszny język Schmidta okazuje się czymś zupełnie innym, niż się wydaje. Nie tyle świadectwem nieugiętej pewności, że wraz z - jak powiedziałby Schmidt - implementacją scjentystycznej terminologii następuję przyrost mocy eksplanacyjnej, ile świadectwem przyjmowania pozycji obronnej, okopywania się na oblężonych pozycjach, szukania schronienia i osłony. Postawa bardzo ludzka, chciałoby się powiedzieć, nawet arcyludzka... Żeby ją lepiej określić, odwołajmy się do słów samego Schmidta. Określa on swe pokolenie mianem międzygeneracji (Zwischengeneration) - z tego powodu, że ludzie urodzeni w latach 1930-1940 nie należą ani do pokolenia synów, ani ojców. I wyjaśnia: „Dla przedstawicieli [tej - przyp. A.S.] międzygeneracji nie było żadnej politycznej ani społecznej organizacji, niewiele poczucia wspólnoty i żadnej wyraźniej społecznej przynależności. Niekończące się dyskusje, zmieniający się idole, niestałe stany uczuciowe, jak też małe i wielkie próby ucieczki kształtowały codzienność. Za poetą i historykiem sztuki Carlem Einsteinem można tę sytuację ująć w słowach: «Nasza tęsknota za koniecznością i wolnością dowodzi realności jedynie samej tęsknoty»" (s. 22). W innym miejscu wspomina Schmidt, jak w odpowiedzi na pomysł opublikowania napisanej przez siebie pracy, zawierającej lingwistyczną krytykę Gadamera, usłyszał od promotora swojego doktoratu pytanie: czy chciałby pan od razu zepsuć sobie karierę? Gdzie indziej opowiada, jak profesorowie przyjęli jego, również lingwistyczną, analizę poezji Trakla: jako racjonalistyczną i pozbawioną respektu profanację (s. 26). W tych wspomnieniach pojawiają się znaczące figury: Nad-Ojców (Übervaters, s. 24) oraz Wielkich Mężczyzn (große Männer, s. 26) - i bez wątpienia warto byłoby spojrzeć na nie psychoanalityczne. Godny pamięci jest ponadto moment, kiedy Schmidt porównuje swoją pracę do losu Camusowskiego Syzyfa i zgadza się, że nie pozostaje nam nic innego, niż wyobrażać go sobie jako kogoś szczęśliwego. A zaraz potem daje w kontekście swoich wykładów (Abtrittsvorlesungen) pewną, cyniczną, jak powiada, anegdotę: „[Czy] Abtritt [ustąpienie - przyp. A.S.] jest staroaustriacką nazwą na toaletę - nie, na klozet!" (s. 10; co znaczy chyba: nazywamy nasze spotkanie wykładem pożegnalnym, ale nie oszukujmy się, jest to po prostu spuszczenie emeryta razem z wodą klozetową). 
Ciekawe jest też to, w jaki sposób Schmidt rozumie swoje niegdysiejsze oświadczenie, że konstruktywizm to nowy paradygmat w nauce ${ }^{4}$. Mówi: owszem, konstruktywizm dokonał tego, że w nowy sposób postawił niektóre podstawowe problemy filozoficzne. Nie doszło jednak do zmiany paradygmatu, konstruktywizm nie stał się też częścią nowego filozoficznego mainstremu. Ale myślę, że to dobrze, stwierdza Schmidt. „Tu [w konstruktywizmie] chodzi [bowiem - przyp. A.S.] o propozycje, a nie o prawdy. Te propozycje można przyjąć - na tak długo, jak są użyteczne - albo odrzucić, co wolno zrobić bez bólu utraty. To jest jedna z lekcji przygodności, o której traktują te wykłady" (s. 107). Rozumiem te słowa następująco: pisałem tak wiele, wyznaje ogródkami Schmidt, tak często zaczynałem na nowo ten sam trud, gdyż nie mogłem poradzić sobie z poczuciem przygodności wszystkiego, co robię. Z ową, a jest to fraza powracająca w wielu jego ostatnich pismach, Endgültigkeit der Vorläufigkeit - ostatecznością przygodności. Tak jakby - może zabrzmi to kiczowato, a może nawet po pascalowsku - otwierała się w nim pustka, którą zasysał wciąż nowe idee, usiłując uśmierzyć niepokój.

W Nauce przygodności Schmidt niczego się nie wyrzeka; nie podkreśla przełomów, lecz ciągłość własnego myślenia; najbardziej zależy mu na tym, aby pokazać, w jaki sposób wszystko, co zrobił, wynika z wyjściowych przesłanek zawartych w jego wczesnych pracach z zakresu lingwistyki. To wiedzie do pewnych przewartościowań: konstruktywizm to niejako punkt obrotowy; bazą okazuje się pragmalingwistyka; Medienkulturwissenschat ostatnim (ze znakiem zapytania) rozszerzeniem (Erweiterung), nie zaś zwieńczeniem całości. Zwieńczenie to książka Geschichten und Diskurse, w której podtytule Schmidt żegna się z konstruktywizmem, ale tylko po to, aby zaraz się przywitać z jego nową, ulepszoną wersją ${ }^{5}$. Ewolucję, którą przeszedł, zamyka w następujących punktach (warto je przytoczyć, bo świetnie pokazują nieustającą atrakcyjność jego myślenia, s. 148):

- rozszerzenie kontekstu: od słowa do zdania, tekstu, dyskursu, kultury medialnej;

4 Zob. np. Od tekstu do systemu. Zarys konstruktywistycznego (empirycznego) modelu nauki o literaturze, przeł. P. Wolski, przekład przejrzał A. Skrendo, w: Konstruktywizm w badaniach literackich. Antologia, red. E. Kuźma, A. Skrendo, J. Madejski, Universitas, Kraków 2006, s. 217-218.

5 S.J. Schmidt Geschichten und Diskurse. Abschied vom Konstruktivismus, Rowohlt Taschenbuch Verlag, Hamburg 2003. 
- zmiana kierunku: od hermeneutyki do empirii, od izolowanego tekstu do tekstu pojmowanego jako część społeczno-symbolicznego systemu literatury;

- przełom epistemologiczny: od obiektu do obserwatora, od obserwatora do procesu;

- zwrot teoretyczno-naukowy: pragmatyczna koncepcja teorii naukowej, od alternatyw do programów badawczych (czyli: przejście od wizji „od jednego do drugiego" do wizji „od jednego do wielości”; idea Lakatosa).

Wszystko to w myśl założenia, które warte jest dwóch przytoczeń. Pierwsze: „czysto racjonalistyczne koncepcje wiedzy są niewystarczające, społeczno-kulturowe, psychologiczne, ekonomiczne i polityczne aspekty grają ważną rolę w i dla scientific community" (s. 50). Ale choć - to przytoczenie drugie - „prawda jest nieosiągalna, staraliśmy się przynajmniej być wierni regułom klarowności i konkluzywności oraz pozostawać blisko praktyki roboty naukowej jako nieodłącznych i najużyteczniejszych instrumentów kontyngentnego rozwiązywania problemów. Żeby redukować opisane przez Marksa panowanie ludzi nad ludźmi, szukaliśmy dających się nauczać i wyuczyć naukowych praktyk i instrumentów: intersubiektywności i interdyscyplinarności, a także uzyskać dającą się stosować wiedzę" (s. 61). Postawa taka, rzecz jasna, rodzi paralelne nieporozumienia. Podpada pod oba zarzuty naraz: zarówno ulegania postmodernizmowi, jak i wyznawania konserwatyzmu. Może sprawiać wrażenie starego oświeceniowego gadania; ale, jak myślę, choć to gadanie jest stare we wnioskach, to nie jest takie w przesłankach. Być może to najlepsza wersja oświecenia, której nadal warto dziś bronić.

Jak łatwo zauważyć, dynamika rozwoju Schmidta podsuwa nam jeszcze jedną formułę podwójności: otóż Schmidt nie ustaje w wysiłkach przedstawienia konstruktywizmu jako filozofii niedualistycznej. Przywiązuje dużą wagę do krytyki Josefa Mitterera, który podkreślał (jak wielu innych), że konstruktywizm przyjmuje idealistyczne, kantowskie założenia: o tyle, o ile odróżnia realność (porządek odkrycia, finden) od rzeczywistości (porządek wytwarzania, er-finden) $)^{6}$.Tymczasem nie ma drugiej strony dyskursu - chyba że w dyskursie. A obiekt opisu nie daje się odróżnić od opisu obiektu. Jakiego

6 Zob. J. Mitterer Das Jenseits der Philosphie, Wien: Passagen Verlag. Po polsku ukazała się późniejsza książka Mitterera: Ucieczka z dowolności, przeł. A. Zeidler-Janiszewska, Oficyna Naukowa, Wrocław 2004. 
rodzaju (nie)ufundowaniem jest zarysowana w Geschichten und Diskurse koncepcja Setzung/Voraussetzung, pokazująca konstruktywizm jako filozofię niejako autokonstytuującą się, bez odwołań do „strony spoza dyskursu”, w tym też do osiągnięć hard sciencies, takich jak neurobiologia - to kwestia osobna. Można logikę tej autokonstytucji rozumieć w duchu gier językowych Wittgensteina, można w duchu fichteańsko-heglowskim. Podkreślanie autologiczności konstruktywizmu - że jest on dyskursem o dyskursie, językiem o języku, mową o mowie, komunikacją o komunikacji - mogło by również wieźć w stronę Luhmanna. Ten jednak pojawia się na krótko i w zasadzie tylko raz, jako kolega z Bielefeld, który wymyślił wizję komunikacji bez aktorów.

„VierzigJahrealso, aberkein Fazit [A zatem 40 lat - ale żadnych podsumowan przyp. A.S.].Z pewnością - spojrzenie w przeszłość i w żywe doświadczenie ostateczności przygodności". To formuła, która całkiem nieźle ujmuje sens książki Schmidta. Ale można by też powiedzieć: „Drogi, nie dzieła” (za Heideggerem). Albo: „Słuchajcie mnie, bo jestem ten a ten. A przede wszystkim nie mylcie mnie z innymi" - za Nietzschem. Tak - Siegfried J. Schmidt, dając nam Naukę przygodności, dał nam swoje Ecce homo. Jak sądzę, nie stało się tak przez przypadek.

Schmidt nawiązuje do Nietzschego w ostatnim zdaniu swej książki - ale nie wprost (s. 150). Zapisuje myśl Helmutha Eisendlego, który napisał, że Nietzsche miał rację, gdy pisał, że jedynie poeta wie, jak rzeczywiście doceniać przygodność... Potem raz jeszcze przypomina, że jest również poetą, przywołuje w całości swoje dwa wiersze - i kończy... Czy chce przez to powiedzieć coś więcej niż powiedział powołujący się na Nietzschego Eisendle: że trzeba zostać poetą, aby mieć siłę afirmować przygodność? Jeśli tak, to dochodzimy do wniosku, że rozwój Schmidta przebiegał od nauki do poezji, od nadziei pewności do apoteozy przygodności oraz od pragnienia stałości do pochwały stawania się. Trzeba przyznać - bardzo nietzscheański punkt dojścia.

Na koniec sięgnijmy zatem po Ecce homo. Wysysanie życia, pozbawianie go krwi, wampiryzm - tak nazywa Nietzsche na końcu swej książki wszystko to, co kojarzy mu się z wiarą w naukę, pewność i stałośćn. Niemoralne wnioski. Niebezpieczne sformułowania. Groźna wiedza. Nawet gdy się do niej z upływem lat zbliżamy, lepiej trzymać się w bezpiecznej odległości. Tak jak Schmidt. Ale niezupełnie mu się to udało - na szczęście. Nawet jeśli ma

7 Zob. F. Nietzsche Ecce homo. Jak się staje, czym się jest, przeł. i przedm. B. Baran, Wydawnictwo Suszczyński i Baran, Kraków 1996, s. 133. 
rację, sądząc - a tak chyba sądzi - że Nietzsche, zwalczając wampiryzm, sam stał się wampirem.

\section{Abstract}

\section{Andrzej Skrendo}

UNIVERSITY OF SZCZECIN

Vampirology - How One Becomes What One Is

Skrendo discusses Siegfried J. Schmidt's 2012 book Lehren der Kontingenz: Erinnerung an 40 Jahre Doppelleben [Teaching Contingency: Remembering 40 Years Double Life]. The focus is on questions of autobiography, but also on the forms of radical constructivism, which is Schmidt's philosophical and theoretical position. The vampire motif that appears in Schmidt's memoirs is a figurative representation of the German Geisteswissenschaften - the arts or humanities - which Schmidt opposes even as he remains dependent on them.

\section{Keywords}

radical constructivism, autobiography, humanities, Siegfried J. Schmidt 